\title{
ENGINEERING STUDY TO DEVELOP A FEEDING MECHANISM ATTACHED TO RICE STRAW CUTTING MACHINE
}

\author{
Salim R. G.*, Shetewy M. A. ** and Abd Alla T. H. ***
}

\begin{abstract}
Rice straw consider one of the main problems face agriculture production in Egypt and its assembly caused a bad effect on environment, , therefore use rice straw pieces in animal fodder as mixture with clover consider one of the most suitable solve of this problem.
\end{abstract}

The main aim of this study, developed and manufactured mechanism attached local rice straw cutting machine solving jamming of rice straw during feeding process to consequently irregular cutting process, resulting in similar rice straw pieces.

Developed mechanism tested with rice straw material; there are three variable factors to evaluate the ability of developed mechanism to cut rice straw into similar and small peaces. The first one, four ratios between feeding drums rotating speed $\left(S_{f}\right)$ to cutting drum rotating speed (Sc), 1/2, 1/4, 1/6 and 1/8 respectively. second factor, number of knives on cutting drum (N) 2 and 4 knives. Third factor the concave clearance between cutting drum and concave of its housing $(\mathrm{Cc}) 2,4$ and $6 \mathrm{~cm}$. To evaluate the influence of previous factors there were theoretical study done to calculate the length of straw pieces at previous factors under study, and then compare the theoretical calculated and actual rice straw pieces after cutting process to estimate the factors that gives the similar and smallest rice straw pieces. The final results of this study can be summarized as follows:

The problem of jamming solved after modifying feeding device attached the cutting machine with new technique. the smallest length of rice straw pieces $(1.8 \mathrm{~cm})$ obtained at number of (4 knife) on cutting drum and the highest value of ratio between feeding drum rotating speed to cutting drum rotating speed $\left(S_{f} / S_{c}=1 / 8\right)$ with concave clearance $(C c=2 \mathrm{~cm})$.

\footnotetext{
*Agric. Eng. Res. Inst. Agric. Res Center.

** Assoc. prof. and chairman of Agric. Structures and environmental control Eng. Dept. Fac. of Agric. Eng., Al-Azhar Univ.

***Agric. Eng. Dept., Agric. Fac. Mans. Univ.
} 


\section{INTRODUCTION}

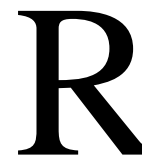

ice crop in Egypt was cultivated on an area of about 1.60 million feddans Food and Agriculture Organization FAO, (2005). produced. That huge amount of rice straw must be collected as soon as possible after grain harvesting to avoid delaying the following field operations and for reducing weather risks. There were a few practical uses for these by-products, up till now. Hence, farmers in Egypt almost burned nearly of 2-3 million tons of rice straw annually and that leads to huge environmental pollution problems, effect of public health and others.

Pasikatan et al (1997) mentioned that using chopper performance with three materials (Napier grass, corn stalks and rice straw) was satisfactory. For corn stalks indicated the best setting was 1150 r.p.m at $2.0 \mathrm{~mm}$ concave clearance this setting gave $1062 \mathrm{~kg} / \mathrm{h}$ capacity and specific energy of $1.7 \mathrm{~kW} . \mathrm{h} / \mathrm{Mg}$.

El-Iraqi and El-Khawaga (2002) showed that the maximum percentage in cutting length of less than $5 \mathrm{~cm}$ of $87.8 \%$ and $92.0 \%$ achieved for rice straw and corn stalks residues, respectively at cutting speed of $10.09 \mathrm{~m} / \mathrm{s}$, feeding rate of $0.77 \mathrm{ton} / \mathrm{h}$ and knife clearance of $1.5 \mathrm{~mm}$.

Kamel et al, (2003) using the forage chopper for chopping rice straw. They found that the maximum values of chopping cost were 22.07 L.E/fed. (12.46 L.E/ton). When chopping rice straw under forward speed of $0.53 \mathrm{~m} / \mathrm{s}$ and moisture content of $13.49 \%$ with 12 cutter head knives.

Metwalley ea al, (2006) developed a chopper machine for agricultural residual. They found that the increase of cutter head speed from 0.75 to $1.88 \mathrm{~m} / \mathrm{s}$ tends to increase the chopping length by 24.1 and $60.5 \%$ for serrated and straight edge shapes respectively.

El-khateeb and El-keway (2012) showed that the maximum percentage of $<2 \mathrm{~cm}$ cutting length of $93.3 \%$ was obtained at cutting speed of 1500 r.p.m and moisture of $22.0 \%$ (w.b) of rice straw.

The aim of the present work is the development of the performance of developed feeding device in straw residues chopper for solving the jamming problem. The items to obtain the aim of the present study are: 
(1) manufacture the developed feeding device for control jamming problem. (2) Evaluation of developed feeding device attached chopper machine before and after development. (3) Manufacture of developed device from local material. (4) Developing device cost.

\section{MATERIALS AND METHODS}

This study was to develope and evaluate a simple feeding mechanizm attached local rice straw cutting machine to solve a problem of straw jamming, the developed feeding mechanism was manufacture from cheap raw materials in local worshop in Al-Dakahlia governorate, Al-Manzala center aimed to cut rice straw into small pieces, the physical and mechanical properties of a rice straw demonstrated in table (1)

Table (1) :The physical and mechanical properties of a rice straw

\begin{tabular}{|c|c|c|}
\hline \multicolumn{3}{|c|}{ Rice straw } \\
\hline \multicolumn{2}{|c|}{ Dimensions } & \multirow{2}{*}{$\begin{array}{c}\text { Moisture } \\
\text { content }(\%)\end{array}$} \\
\hline Mean length $(\mathrm{cm})$ & Mean thickness (mm) & \\
\hline 55 & 4.6 & 15.5 \\
\hline
\end{tabular}

Several points taken into consideration when manufacturing developed feeding mechanism.

1 - Made from available and cheap raw materials in a local market.

2 - Easy removal and installation, maintenance and cleaning various parts.

3 - light weight and self source of power (7 Hp Diesel engine), can be moved and maneuver in places of assembly rice straw.

5 - Minimum cost to an increase in profit.

The machine containing two main units:

\section{- Developed feeding mechanism:}

A pair of drums (diameter, $10 \mathrm{~cm}$ ), the lower drum take the movement from cutting drum that take its movement from main motor by belts and pulleys on its axis, upper drum was manufactured so that it can move up at jamming by modifying part as shown in (Fig.1) consists of movement light curve plate, spring and three sprockets $(18,36$ and 18 teeth respectively) connected by chain to regularize movement between feeding drums. 

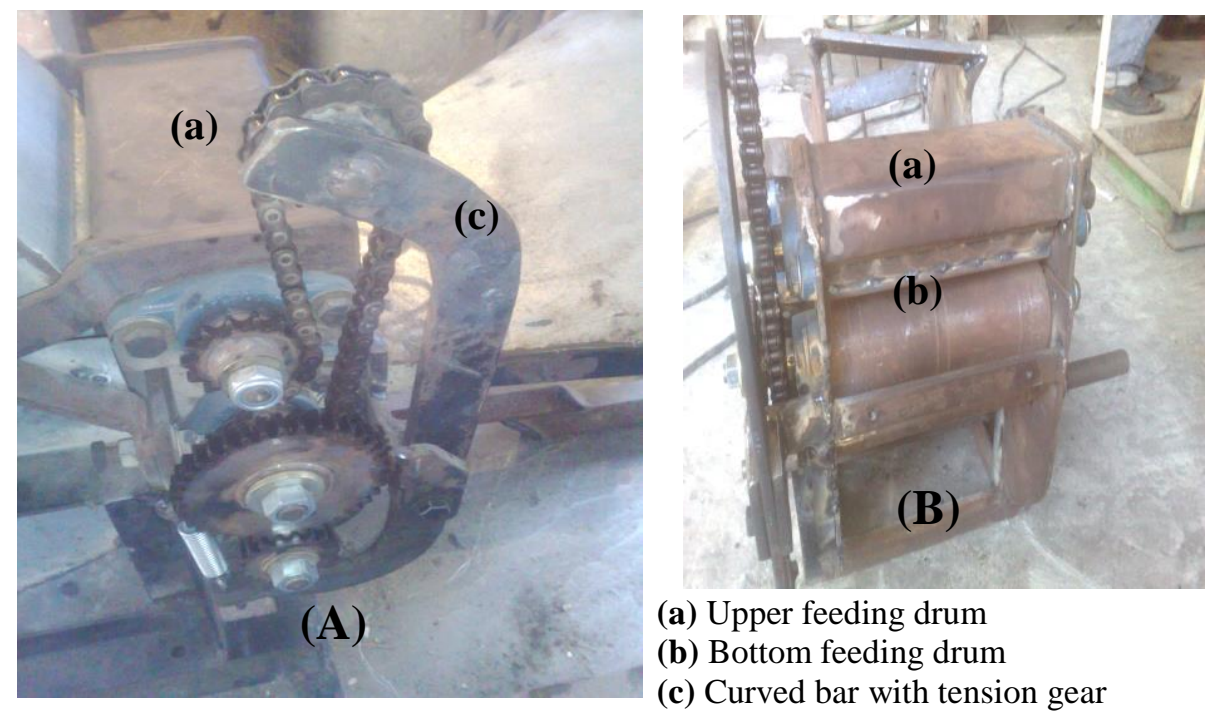

(a) Upper feeding drum

(b) Bottom feeding drum

(c) Curved bar with tension gear

Fig. (1, (A and B)): The modifying part during the manufacturing process in the workshop

\section{- Rice straw cutting unit}

The straw cutting unit consists of cutting drum (diameter $30 \mathrm{~cm}$ ), with free motion and contains the ( 2 and 4 cutting knives) distributed on the longitudinal axis and takes its movement of diesel motor ( $7 \mathrm{Hp}$ ) by pulleys and belt .

The main components of the developed straw cutting machine demonstrated in Fig. (2).

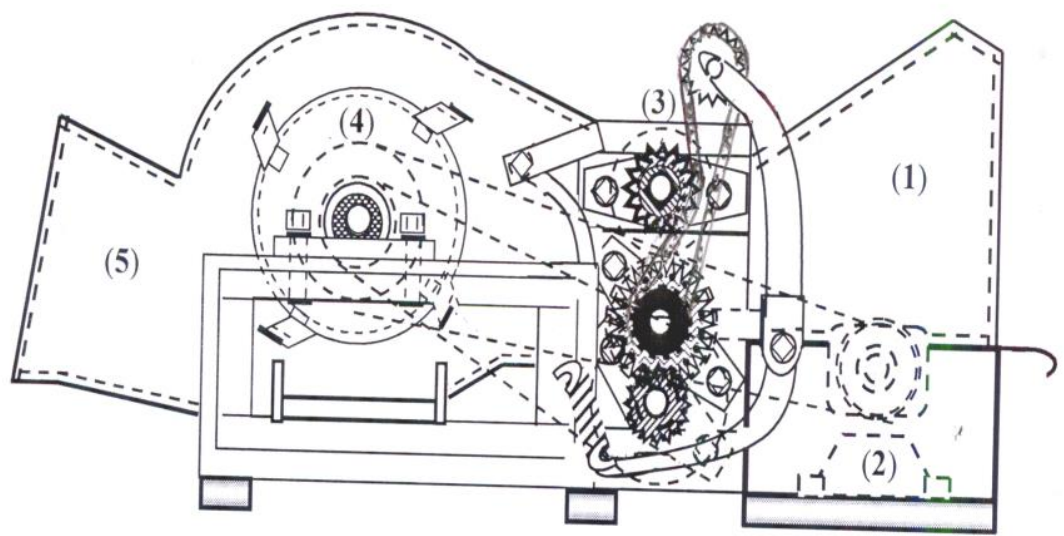

(1) Straw entry slot (2) Diesel engine (3) Developed feeding system

(4) Straw cutting knives unit(5) Straw exit hole section

Fig. (2): A side view for the machine shows the main parts 


\section{Machine transmission system:}

\section{1) Cutting unit}

The main source of power is a $(7 \mathrm{Hp})$ Diesel motor with 2100 r.p.m attached with pulley (5 cm Diameter.) on its axis, that transfer the movement of motor directly to cutting drum by belt and pulley.

The main axis of cutting drum attached with a pulley with $(10 \mathrm{~cm})$ diameter for enable to reduce revolution of motor from 2100 r.p.m to 1050 r.p.m of cutting drum $\left(\mathrm{S}_{\mathrm{c}}\right)$.

\section{2) Developed feeding mechanism}

This mechanism takes its movement directly from cutting drum, the pulley with (5 $\mathrm{cm}$ Diameter.) attached the cutting drum axis and transfer the movement by belt, (5, 10, 15 and $20 \mathrm{~cm}$ Diameter) pulleys attached the axis and transfer the movement to lower feeding drum by spur gears (18 and 36 teeth) as shown in Fig. (3). The upper feeding drum takes its movement from lower drum by two sprocket gears (18 teeth) and chain connected them.

This enable to reduce the ratio of the feeding drum revolution $\left(\mathrm{S}_{\mathrm{f}}\right)$ to cutting drum revolution $\left(S_{c}\right)$ to $1 / 2,1 / 4,1 / 6$ and $1 / 8$ respectively.

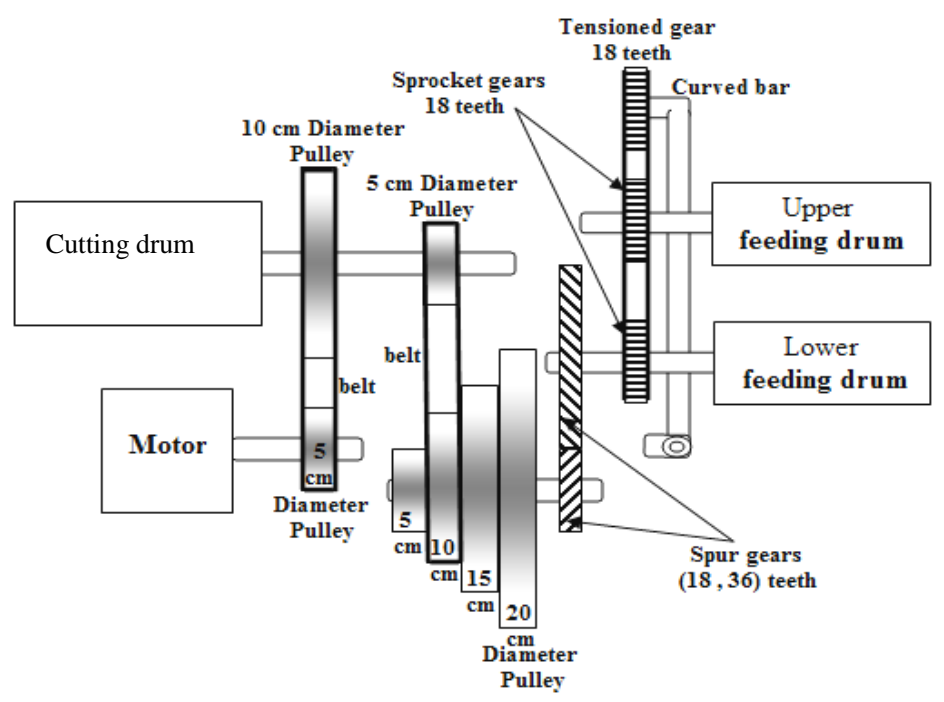

Fig. (3) : Diagram demonstrates machine parts transmission system 


\section{The experimental factors :-}

There were three experimental factors under study to assess the performance of machine as flow:

1) Ratio between feeding drum rotating speed to cutting drum rotating speed $S_{\mathrm{f}} / \mathrm{S}_{\mathrm{c}}(1 / 2,1 / 4,1 / 6$ and $1 / 8)$.

2) Number of knives on cutting drum (N) (2 and 4 knives).

3) The concave clearance (Cc) of cutting drums $(2,4$ and $6 \mathrm{~cm}$.)

\section{The experimental measuriments :-}

\section{1) Lengths of cutting rice straw:}

Performance evaluation of the developed feeding mechanism and the effect of previous factors on this performance, the theoretical and experimental length of rice straw pieces after cutting (L) were estemated. After each cutting treatment a sample of one $\mathrm{kg}$ from cutting crop material was taken as a random sample after each factor under study, then calculated lengths of these pieces and the expense of average length estimated as the experimental measuriments. Each cutting length in the sample was wieghed and calculated as apercentage from the total weight of the sample. Also, the comparative study was done.

\section{2) Machine productivity:}

Calculated by using the following formula acording to El-Khateeb. and El Keway (2012)

$$
\mathrm{P}=\mathrm{Wx} 3600 / \mathrm{T}, \mathrm{Mg} / \mathrm{h} \text {. }
$$

Where: $\mathrm{P}=$ productivity $(\mathrm{Mg} / \mathrm{h})$.

$$
\begin{aligned}
& \mathrm{W}=\text { mass of the sample }(\mathrm{Mg}) \text {, and } \\
& \mathrm{T}=\text { time (min.). }
\end{aligned}
$$

\section{Theoretical consideration}

Through the machine design and perevious factors under study, it can be estimate the theoretical length of rice straw pieces after cutting, and the following equation can be drown

\section{where}

$$
\boldsymbol{L}=\frac{S_{f}}{S_{c}} \times \frac{\pi \times D_{f}}{N}
$$

$\mathbf{L}=$ Theoretical length of rice straw pieces after cutting $(\mathrm{cm})$.

$\mathbf{S}_{\mathbf{f}}=$ Feeding drums rotation speed (r.p.m).

$\mathbf{D}_{\mathbf{f}}=$ The feeding drum diameter $(\mathrm{cm})$. 
$\mathbf{S}_{\mathbf{c}}=$ Cutting drum rotation speed (r.p.m)

$\mathbf{N}=$ number of knives on cutting drum.

Theoretical lengths of rice straw pieces after cutting process were estemated as showen in table (2) through the previous equation at four categorys of ratios between feeding drum and cutting drum rotating speed $S_{\mathrm{f}} / S_{\mathrm{c}}(1 / 2,1 / 4,1 / 6$ and 1/8), two number of knives on cutting drum ( 2 and 4 knives), feeding drum diameter $D_{\mathrm{f}}(10 \mathrm{~cm})$, the theoretical and experimental lengths of rice straw pieces after cutting process were determine and the obtained results were discussed.

Table (2): Theoretical lengths values calculated of rice straw pieces (cm) at various factors under study

\begin{tabular}{|c||c|c|c|c||}
\hline \multirow{2}{*}{$\begin{array}{c}\text { Number of } \\
\text { knives on } \\
\text { cutting drum }\end{array}$} & \multicolumn{4}{|c||}{$\begin{array}{c}\text { Feeding drum rotating speed / Cutting drum } \\
\text { rotating speed }\end{array}$} \\
\cline { 2 - 5 }$\left(\mathbf{S}_{\mathbf{f}} / \mathbf{S}_{\mathbf{c}}\right)$
\end{tabular}

\section{RESULTS AND DISCUSSION}

\section{Percentage of cutting length:}

This experiment conducted in order to evaluate a performance of developed feeding mechanism and determine the best collection of factors under study that gives a smallar and simillar pieces of cutting rice straw.

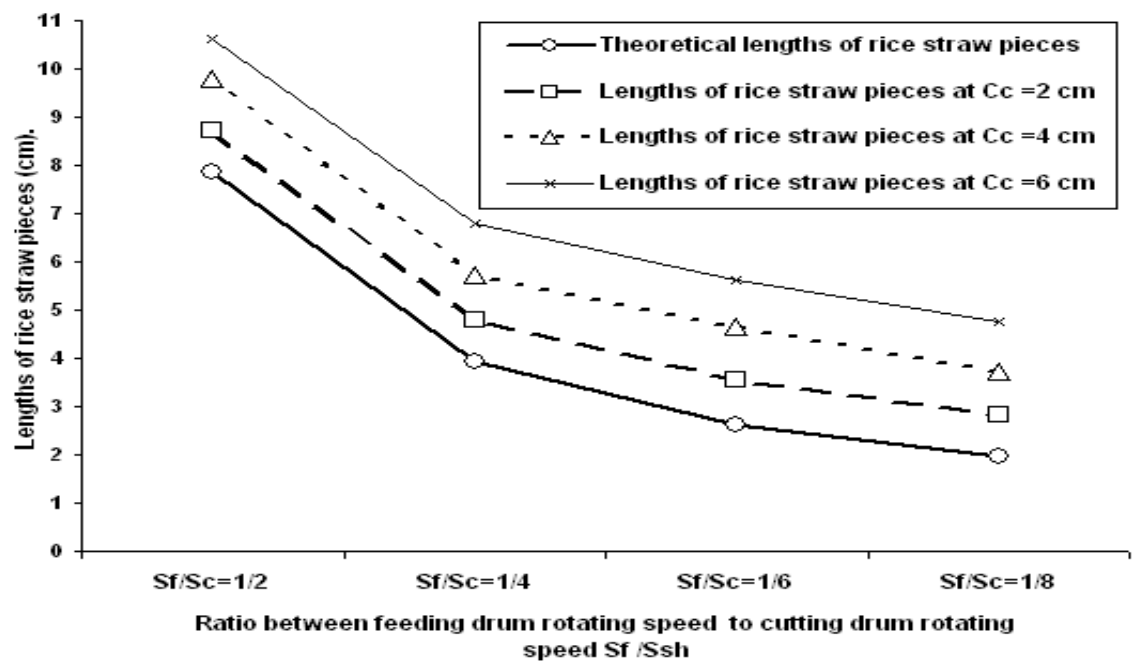

Fig. (4): Lengths of rice straw pieces at various concave clearance (Cc) under study and a number of 2 knives on cutting drum. 


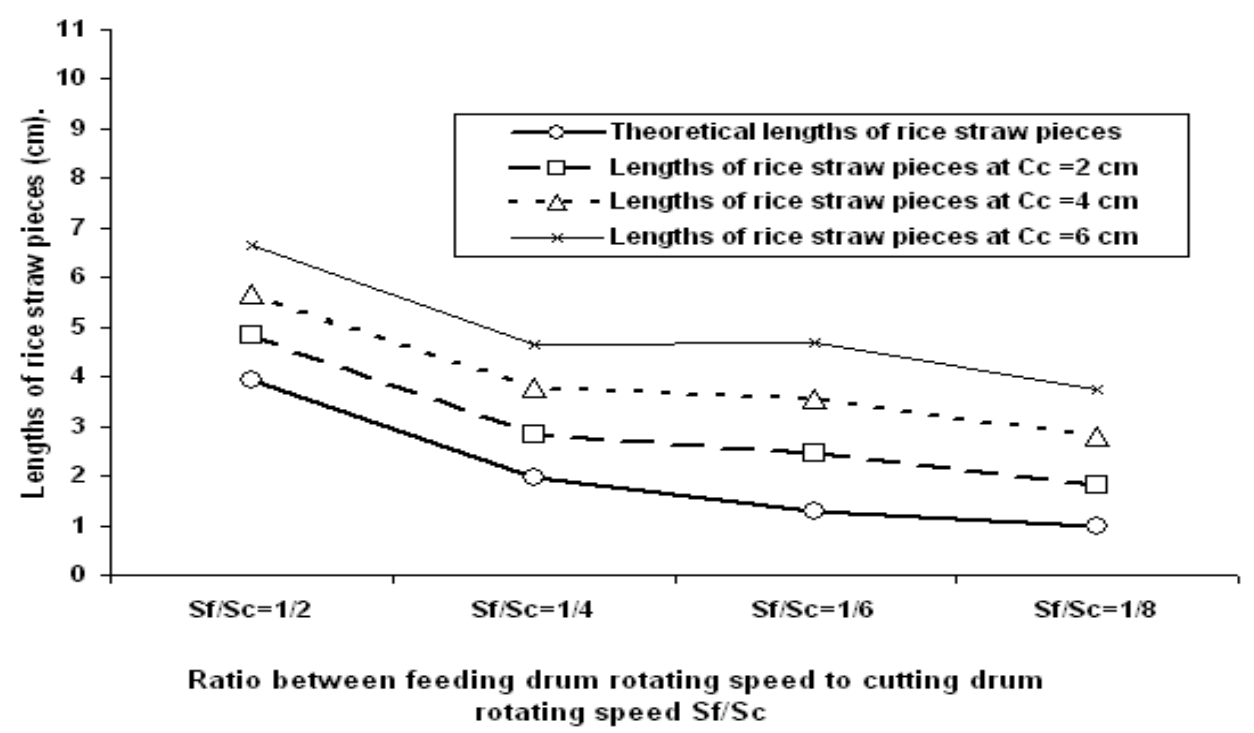

Fig.(5) Lengths of rice straw pieces at various concave clearance (Cc) under study and a number of $\mathbf{4}$ knives on cutting drum.

Figs. (4 and 5) showed that, largest length of rice straw pieces $(10.62 \mathrm{~cm})$ as shown in (fig. 4) obtained with number of (2 knives) on cutting drum and the lowest value of ratio between feeding drum rotating speed to cutting drum rotating speed $\left(\mathrm{S}_{\mathrm{f}} / \mathrm{S}_{\mathrm{c}}=1 / 2\right)$ with concave clearance $(\mathrm{Cc}=6$ $\mathrm{cm})$, where the smallest length of rice straw pieces $(1.8 \mathrm{~cm})$ as shown in (fig. 5) obtained with number of (4 knife) on cutting drum and the highest value of ratio between feeding drum rotating speed to cutting drum rotating speed $\left(\mathrm{S}_{\mathrm{f}} / \mathrm{S}_{\mathrm{c}}=1 / 8\right)$ with concave clearance $(\mathrm{Cc}=2 \mathrm{~cm})$. this may be due to, exposing the straw to number of strikes more than the above factors.

\section{Cutting machine productivity $(\mathrm{Mg} / \mathrm{h})$ :}

The results of cutting machine before and after modifying of feeding device shown in table. (3) From these results could be indicated that an increasing number of knives from 2 to 4 led to an increment in the cutting machine productivity, $\mathrm{Mg} / \mathrm{h}$.. From the same mentioned data, one can see that, the cutting machine productivity before modified the feeding mechanism less than after modifying, where, achieved the 
maximum value $(1.78 \mathrm{Mg} / \mathrm{h})$ at four knives, the highest value of ratio between feeding drum rotating speed to cutting drum rotating speed $\left(\mathrm{S}_{\mathrm{f}} /\right.$ $\left.\mathrm{S}_{\mathrm{c}}=1 / 8\right)$ and concave clearance $(\mathrm{Cc}=6 \mathrm{~cm})$

Table 3: Effect of studied factors on the cutting machine productivity before and after the modifying of feeding mechanism.

\begin{tabular}{|c|c|c|c|c|}
\hline $\begin{array}{l}\text { Number of } \\
\text { cutting }\end{array}$ & $\begin{array}{l}\text { Ratio between } \\
\text { feeding and } \\
\text { rotating drum }\end{array}$ & \multirow{2}{*}{$\begin{array}{l}\text { Concave } \\
\text { clearance } \\
\text { (cm) }\end{array}$} & \multicolumn{2}{|c|}{$\begin{array}{c}\text { Cutting machine } \\
\text { productivity }(\mathrm{Mg} / \mathrm{h})\end{array}$} \\
\hline \multirow{13}{*}{ Two knives } & \multirow{4}{*}{$1-2$} & & $\begin{array}{c}\text { Before } \\
\text { modifying }\end{array}$ & $\begin{array}{c}\text { After } \\
\text { modifying }\end{array}$ \\
\hline & & 2 & 0.62 & 0.68 \\
\hline & & 4 & 0.66 & 0.74 \\
\hline & & 6 & 0.74 & 0.85 \\
\hline & \multirow{3}{*}{$1-4$} & 2 & 0.74 & 0.79 \\
\hline & & 4 & 0.79 & 0.86 \\
\hline & & 6 & 0.83 & 0.93 \\
\hline & \multirow{3}{*}{$1-6$} & 2 & 0.77 & 0.84 \\
\hline & & 4 & 0.89 & 0.96 \\
\hline & & 6 & 0.96 & 0.99 \\
\hline & \multirow{3}{*}{$1-8$} & 2 & 0.81 & 0.90 \\
\hline & & 4 & 0.97 & 1.09 \\
\hline & & 6 & 1.12 & 1.23 \\
\hline \multirow{12}{*}{ Four knives } & \multirow{3}{*}{$1-2$} & 2 & 0.78 & 0.89 \\
\hline & & 4 & 0.83 & 0.96 \\
\hline & & 6 & 0.98 & 1.16 \\
\hline & \multirow{3}{*}{$1-4$} & 2 & 0.80 & 0.92 \\
\hline & & 4 & 0.86 & 0.97 \\
\hline & & 6 & 0.96 & 1.19 \\
\hline & \multirow{3}{*}{$1-6$} & 2 & 1.06 & 1.34 \\
\hline & & 4 & 1.14 & 1.47 \\
\hline & & 6 & 1.28 & 1.49 \\
\hline & \multirow{3}{*}{$1-8$} & 2 & 1.15 & 1.58 \\
\hline & & 4 & 1.34 & 1.68 \\
\hline & & 6 & 1.45 & 1.78 \\
\hline
\end{tabular}




\section{CONCLUSION}

The final results of this study can be summarized as follows:

- The problem of jamming solved after modifying feeding device attached to the cutting machine with new technique. the smallest length of rice straw pieces $(1.8 \mathrm{~cm})$ achieved at number of $(4$ knife) on cutting drum and the highest value of ratio between feeding drum rotating speed and cutting drum rotating speed $\left(\mathrm{S}_{\mathrm{f}}\right.$ $\left./ \mathrm{S}_{\mathrm{c}}=1 / 8\right)$ with concave clearance $(\mathrm{Cc}=2 \mathrm{~cm})$.

- The maximum value $(1.78 \mathrm{Mg} / \mathrm{h})$ obtained in developed machine at four knives, the highest value of ratio between feeding drum rotating speed to cutting drum rotating speed $\left(\mathrm{S}_{\mathrm{f}} / \mathrm{S}_{\mathrm{c}}=1 / 8\right)$ and concave clearance $(\mathrm{Cc}=6 \mathrm{~cm})$

- The problem of jamming solved with modifying new technique.

\section{REFFERENCES}

FAO (Food and Agriculture Organization) (2005). http://www.fao. ess/ top/ country.html.

El-Iraqi, M and S. El-Khawaga (2003) " Design and test performance of cutting machine for some crop residues" Misr j. Agr. Eng., 20 (1): 85-101.

Pasikatan, M. C. , G. C. Salazar and G. R. Quick (1997). " A low - cost straw and forage chopper." AMA, 28 (1): 43-46.

Kamel, O. M., M. El-Iraqi and M. Egela (2003)." Maximizing utilization of for age chopper for chopping rice straw residues Misr j. of Agr. Eng. 20 (3) 751-766.

Metwalli M. M., I sayed ahmed, N Mansour and A. El-Nagar (2006). " Development of a chopping machine for Agricultural residual ( A 
case study on grape trashes) J. Agr. Sc. Mansoura Univ. 31 (5) $2943-2955$.

El-Khateeb H. A. and A. El Keway (2012)." Development and Evaluation of cutting knives to suit cutting wet and dry field residues" J. soil sc. And Agr. Eng. Mansoura Univ. 3 (6) 601 -616.

الملخص العربي

\section{دراسة هندسية لتطوير وحدة تغذية ملحقة بآلة لتقطيع قش الأرز

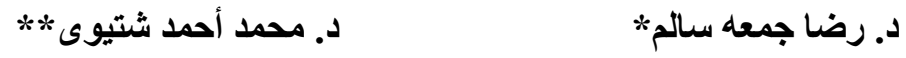

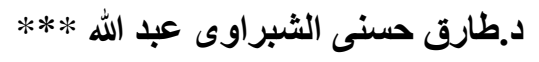

يعتبر قش الأرز من المخلفات الزراعية و التى يجد المزارع المصرى صعوبة فى التخلص منها

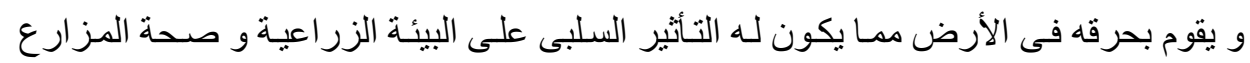

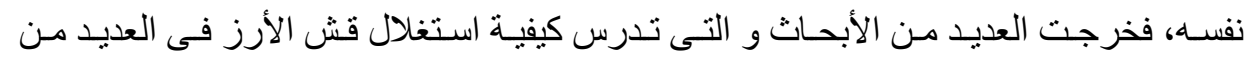
الصناعات أو استخدامه كعلف للمانثية و ذلك بخلطه مع مو اد مرتفعة القيمة الغذائية مثل البرسيم و لذلك يلزم تقطيع قش الأرز إلى قطع صغيرة لسهولة خلطه بالأعلاف الحيو انيـة المركزة منها

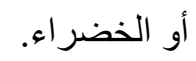

بدأت ظهور آلات لتقطيع قش الأرز محلية الصنع ذات تلقيم يدوى مبانشرة إلى درفيل التقطيع

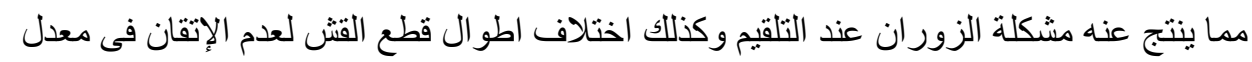
التغذية.

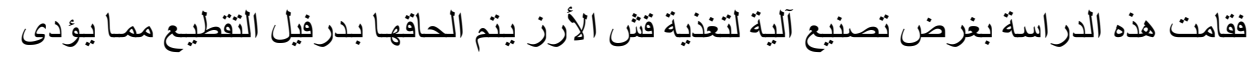

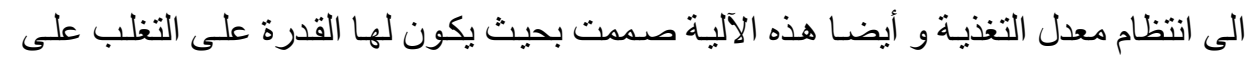

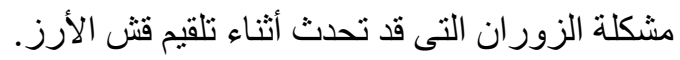
و لار اسة تأثثر نظام التغذية المطور على انتظام اطو ال قطع قش الأرز، تم اجراء در استة نظرية

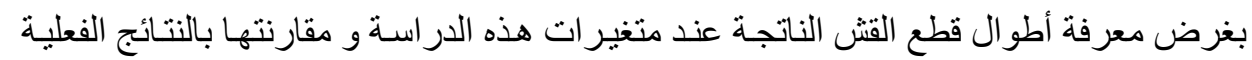

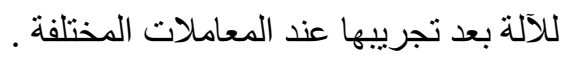

* معهز بحوث الهندسة الزراعية ** استاذ ورئيس قسم المنثآت الزراعية والتحكم البيئي المساعد ـ كلية الهندسة الزراعية - جامعة الازهر بالقاهرة.

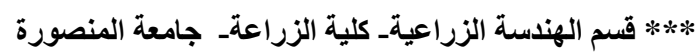




\section{و تمثلت متغيرات الاراسة فيما يلى:}

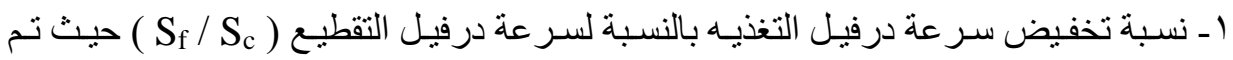

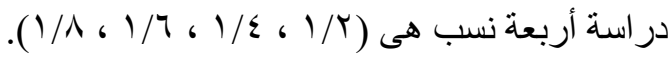

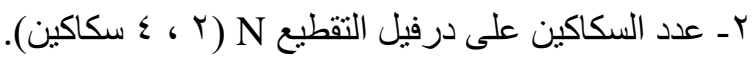

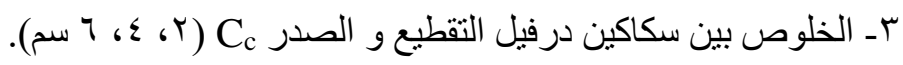

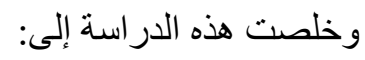

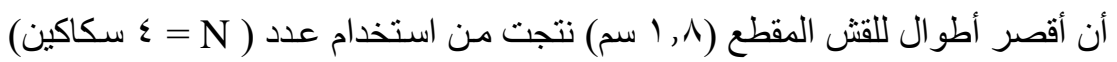

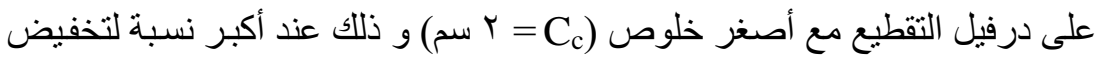

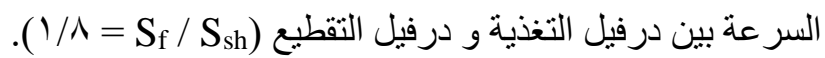

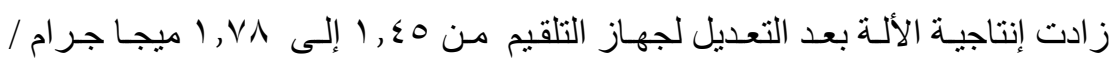

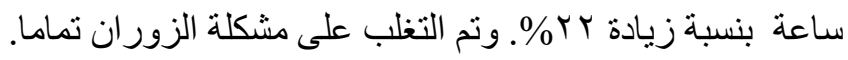

